\title{
EXCLUSION FROM PARTICIPATION IN POLITICS; EBONYI STATE, NIGERIA: NATIONAL DEVELOPMENT QUESTIONS
}

\author{
Joy Ucha Egwu (Ph.D) \\ Department of Political Science, Ebonyi State University, Abakaliki, E-Mail: joy.ucha@gmail.com
}

\begin{abstract}
The study examined the implications of excluding women from participation in the politics of Ebonyi State and its national development consequences. The study was predicated on the patriarchal theory which basically rationalizes and projects male dominance in political contestations. We relied on documentary method of data collection and hence collected our data through secondary sources. Data were analyzed through content and textual analysis. The objectives of the study were to determine the extent to which socioeconomic and cultural factors undermined women's political participation. Specifically, the study interrogated whether the exclusion of women from politics affected the development of Ebonyi State. The study demonstrated that there was a drastic fall in participation of women in Nigerian politics which fundamentally stultified national building and development. The paper recommended that all cultural and traditional harmful practices against women should be abolished in Nigeria by Government's strong policies which must be implemented and enforced accordingly.
\end{abstract}

Keywords: Exclusion, Governance, Development, Dominance, Women, Inequality.

\section{INTRODUCTION}

Developed societies and sustainable governments rely on the participation of all the citizens in the country. Developments and its sustainability also depend upon the equality of all citizens under the law, Anifowose; (2014). During the precolonial periods, females held important positions in the society. They made a mark in the political participation and development of the country, contrary to what it is today, as they were grouped into different stages in relation to the diverse political structure of the country. In line with the structural position of Nigeria, the political position of women differed according to the cultural orientation of an ethnic group or religion. Women's positions varied however according to "kinship" structure and their role within the economic structure of the society.

Traditionally, women assumed their roles as mothers and care givers in the society. Also, they were regarded at the same time as complementary to men rather than subordinates. Power in the society was mostly based on seniority rather than gender. During the period, women were very active and they contributed tremendously in the agricultural sector, local and long distance trade, commerce and sustenance of kin groups. Furthermore, they were prominent in health care and also participated effectively and efficiently in the administration of the state of the kingdoms (Atteo, 2002). For instance, Igala was found by a woman named Ebele Ajanu (Olatunde, 2010). Other women such as Nana Asmau of Zauzzau and Emotan of Benin and Moremi of Ife were amongst those who displayed tremendous bravery in the politics (Opcit).

In the Hausa society, females had high status during the precolonial period. Bornu women played active roles and held very important offices in the royal family, including the office of the "Megira" (the Queen mother) and "Gumsu" (the first wife of the Mai or king); (Ola 1978 in Attoe, 2002). Also, history recorded that the modern city of Zaria was founded in the first half of the $16^{\text {th }}$ century by a woman called Queen Bakwa Turuku who had a daughter called Amina that subsequently succeeded her as queen. History recorded also that 
Queen Amina was a great and powerful warrior who fought many wars and won in many cases. Furthermore, among other things she built a high wall around Zaria in order to protect the city from invasion and extended the boundaries of her territory beyond Bauchi. In addition, she turned Zaria into a powerful city and a prominent commercial centre. As a result of the recognition of her achievements, the people of Kano, Kaduna and the neighbouring territories still pay tribute to her (Attoe, 2002).

In the west, which is the Yoruba, the females were included in the governance of their empires and their positions were very sensitive because of the important roles they performed. For instance, the "Alafin's" (king) many wives acted as the "eyes" and "ears" of the king. The wives were the "secret service agents" in the course of their trading activities and also they contributed to the smooth running of the palace. For example, these females performed duties as follows: - The "lya Oba" was the king's official Queen mother who gave advice and words of wisdom to the king. The lya Kere wielded great power and authority in the palace. She was the custodian of the palace treasury including the royal insignia and the king's paraphernalia of office. lya Kere was as well responsible for crowning the king during the coronation ceremony. Her political position was of great significance because she could sabotage any of the Oba's (kings) public appearance by refusing to allow him the use of some garments of office, (Afonja, 1996). Furthermore, the lya Lagbon was the mother of the crowned prince who wielded great authority and ruled over a part of the capital city. Lastly, the "lya Lode" was responsible for the Oba's (king) spiritual well-being and also looked after the women's trading interest.

These women mentioned above formed the active class of spokes women for political stability and humane rule as well as for the interest of the females at the highest political level in the kingdom. It is worthy of note that some of these women played the role of warriors and spies in the political development of their kingdoms, such as Moremi of Ife who was a powerful woman. She allowed herself to be captured by their enemies in order to gain information so as to defeat them. The high socio-political status of females in the traditional Yoruba society was also evident among the Edos. Other females such as Nana Asmau of Zazuzau, Idia and Emotan of Benin were among those who also displayed tremendous bravery in politics.

Finally, the Igbos occupied part of the old Eastern Nigeria. Their females had their market and village groups where, through their representatives, "Umu Ada" (ruling females) matters affecting them were discussed at the village meetings. These females were recognized as leading representatives of the market women, "Umu Ada" and age-grade leaders. Females in that era in the various parts of the society, formed powerful associations to enable them present united forces when they elected their leaders to articulate their interest for them. These women were independently powerful as they were employed or influenced more women that enchanced the course of the woman. These women were also looked upon as sources of inspiration for women today as they were an integral part of the political set of their communities. Although they assumed responsibilities different from those of men; in most cases these responsibilities were complementary to those of the men (Attoe 2002).

During the era of colonialism in Nigeria, the women were mostly inactive especially in politics; Badejo (1985). The colonial officials propagated western female stereotypes which assigned women to domestic domains leaving economic and political leadership to men. The colonial development policies focused on men who were the eyes of the White colonial officials. As a result, the adverse effect of colonialism on Nigerian women was glaring in the area of politics. Consequently, women were denied their franchise as the political space was completely dominated by men. Women had no power to take part or contribute in politics until 1950 . Many women lost their land inheritance when new property laws abrogated women's right to ownership of land. This resulted to the transfer of women's lands to men.

During the 1950s, at the height of the clamour for independence, very few women were offered political or administrative appointments because according to Walter (2001), the authority simply refused to acknowledge and interact with female office holders or women associations. As a result, they faded away into the background. Secondly, it was at this time; the 1950s that women in the south were granted franchise while women from the North were still denied franchise until 1978, Egwu (2017). The franchise given to the women in the North, made women to contribute little or nothing in politics. This made this era to be considered as the most uneventful in the area of women's participation in politics and developments. Since the country could not boast of any prominent female nationalists and as can be expected the so called women's wing of the pioneer political parties "possessed little or no functional relevance", Attoe (2002). This was during the revolutionary stages of agitation for the independence of Nigeria.

In the first republic of 1960-1966 after the independence, women's participation in politics was minimal. Many women showed interests in politics but were discouraged by a lot of challenges in politics mostly from unsympathetic men; Yusuf in Badejo (1985). By the second republic (1979-1983) women in the North had been granted franchise and a few more females won election and got appointed. From this second republic 
till date, women's representation and participation in politics can be classified as a "token representation", as women are still very much in the minority, statistically, since the percentage of women's participation in politics in the year 2019 general election dropped to 3.7 percent against 6.4 percentage in 2015 general election.

\section{STATEMENT OF THE PROBLEM}

Nigeria's social, economic and political development has been very slow which has been affecting the populace. The total population of Ebonyi State was 2.2 million, of which women's population was 1.135,517 in 2006 (Census 2006, Federal Bureau of Statistics). The potentials of these women are totally redundant because they are not being utilized, thereby making politics one-sided and non-balanced in Nigeria

A recent United Nations Report concluded that economic development of nations is related to the empowerment of women. In nations where women have been restricted from empowerment the economy has been stagnant or retrogressive. According to the 1995 United Nations Survey, two changes have occurred over the past ten years in the enabling environment for women in the world economy. One is the establishment of legal equality for women. The other is granting women equal access to education and training. These two factors in the enabling environment for women have had significant impact on the global economy of the Highly Development Countries (HDC).

For instance, the Nordic countries have consistently stood out in the world; countries like Finland, Norway, Sweden, Denmark and Iceland have close to over $80 \%$ of their gender gaps filled up. They have long been international champions of gender equality. They explicitly support gender equality at home, at work, and in public life; and have often moved earlier and faster than most countries in taking actions to promote this goal. Today on the average across the Nordic countries, almost three out of every four working-aged women are in paid employment, O. E CD (2018). They were the first countries to provide women with full voting rights; (Hilson 2007; statistics Sweden, 2016). Moreover, these countries have the world highest indicies of quality of life.

According to Wood (2018) Nordic countries all benefits from a developed welfare state and foster forwardthinking initiatives, which support women joining or returning to the work place. The World Economic Forums recently released the Global Gender Gap Report 2018 which shows that dominance of Nordic Countries that take up the top four places. As it stands with their gender gaps almost filled up, there are gains in gender equality and especially gains in female headcount employment which have helped women to make a substantial contribution to economic growth in the Nordic Countries. The steady increase of their women in the labour market can account for $20-30 \%$ of the Nordic region's GDP per capita growth in the past $40-50$ years; OECD report (2018). In 2016 the Nordic Region even had a higher growth rate (2\%) than the US $(1.6 \%)$.

In Nigeria the case is different. Women experience little capacity building or enabling environment to participate actively and effectively in politics and in the social economic and cultural spheres. For instance, Nigerian women have little or no access to wealth, education, high skilled work, the Armed forces or policies aimed at promoting women participation in politics and the filling of voluntary gender quotas. Without these enabling factors, the study assumes that the development of the Nigerian nation may not progress as it should be compared to the Highly Developed Nordic Countries that have enabling environments for their women. Given that the population of women is greater than that of men in Ebonyi State, one expects that the women should be empowered and not excluded in the economy and politics. Powel (1990) and Egwu (2007) argued that women with their intuition can and do set up organisations if empowered, to develop their countries and Ebonyi State is not an exception.

\section{LITERATURE REVIEW}

\section{Conceptual Clarification and Review of Related Literature}

The general level of political participation in a society is the extent to which the people as a whole are active in politics. (Egwu, 2017). Furthermore, she describes political participation as constituting the legal activities by citizens which are directly aimed at influencing the selection of government functionaries who run the affairs of the state, influence their decision making and government policies. With regard to this definition above, political participation involves all citizens' participation and their involvement in playing their parts in their individual nations or states. Factors such as political, cultural, socialization, wealth, constitution, education, religion and gender tolerance determine the level of female participation in any nation. The concepts above may hinder women's political participation in Nigeria.

While women's political participation is defined as the fundamental prerequisite for gender equality and genuine democracy, it facilitates women's direct engagement in public decision making and is a means of 
ensuring better accountability to women, UN WOMEN (2015). It further buttresses the fact that political accountability to women begins with increasing the number of women in decision making positions which requires gender sensitive governance reforms that will make all elected officials more effective at promoting gender equality in public policy and ensuring their implementation. It is noted that one of the pillars of UN WOMEN'S work is advancing women's political participation and good governance, to ensure that decision making processes are participatory, responsive, equitable and inclusive.

Finally, National Development is very broad and comprehensive which includes all aspects of the development of a nation such as politics, social, economic and religion. According to UN Decade Report, (1980). National development is growth plus change. It is the change in growth and development which includes social, cultural and economic changes. It is the ability of a country to improve the life chances and social welfare of the people, and also it entails the expansion of people in a defined territory or government. National development is the process of growth and improvement in the nation - state (Obasanjo 2007). Development in any nation is not a sudden occurrence or event but a product of careful and strategic planning, Marcellus; (2011) posits that development planning comprehensively involves predetermining a nation's visions, missions, policies and programmes in all facets of life such as social, human, political, environmental and technological factors and devising all the means of achieving them. It is worthy to note that the pride of any government is the attainment and sustenance of higher and value added levels of development in which the citizens would derive and participate in goal attainment and governance.

Socioeconomic and cultural factors indicate that women always constitute a small number in political participation because of socioeconomic and cultural factors. The issues of exclusion from socioeconomic and cultural participation have several implications on women and their countries. Okpilike and Abamba, (2013), have opined that Nigeria is a patriarchal society like many other societies of the world where men usually dominate. Agbalajiobi, (2010); states that patriarchal social systems or structure occur when the economic, political and socio-economic powers are dominated by men. Falola (2013) argues that even when men dominated powers and authority, women were given titles such as queens. What are ceremonial titles compared to executive, legislative and judiciary powers where decision are made and executed? As men dominate the society so the society is structured to suit them. For instance, several traditional practices are injurious to women's self-esteem and self-image which are necessary ingredients for the confidence needed in political participation; Yetunde (2008). So many women have been inhibited from political participation by the practice of Moslem purdah (house seclusion of women) of Northern Nigeria. Luka, (2011) stresses that politics in Nigeria is structured to be a dirty vocation that is reserved for unrefined and unscrupulous people, hence the exclusion of women from politics.

The culture according to Wagadu (2008), entails the socialization of a girl child to have or exhibit perceived inabilities on the part of the women. As a result, the life passages of most women in Africa are not sacramentalised, celebrated or even acknowledged. As soon as they are born, their roles are already waiting for them. Wagadu (2008) states that the women's roles are too demanding: home makers, cooking, washing, expecting them to be gentle, providing for their husbands and responsible for their children's upbringing. All these give them no room for political meetings and gatherings that usually run into the mid-nights. Also, Ekpe, Enieja and Egbe (2014) explain further that politics is time consuming and demands great attention. The rituals and the rites of passage pertaining to the boy's nurture on the other hand provide them for leadership positions, whether at home; local and national levels.

Furthermore, in Afikpo North Local Government Area where the author comes from, women are totally excluded from the traditional decision making body by the authority in charge. For instance, the "age-grade" (Essa) is the highest traditional decision making body in Afikpo in Ebonyi state. This traditional institution is dominated by men and no woman is a member. This situation agrees with Muoghali and Abrifo (2012) who said that women are to be seen alone and not to be heard, at least politically.

Apart from the age grade (Essa) system, there are other traditional institutional arrangements where there are ritualistic manifestations and glorification of cultural practices that promote male domination, total female subjugation and control. These other institutions include the; "ogo" system, the "eto" age grade system and the new yam cultural festival system known as "ike-jii or Ahaiajoku system.

In the "ogo" system, the women are not allowed to be seen within the "ogo" setting especially when the elderly men known as "nde-ichie" are seated to take important decisions as they affect the land. However, at the tail end of deliberations, some aged women of title may be invited to join the men for information purposes only, this usually concerns issues of land cultivation and farming rituals.

The "eto"age grade system is the second highest traditional law making and dispute settlement body in Afikpo where women are still not represented, but are made to comply with the laws made by their male counterparts even when it does not favour the women folks. Women of course have their own age grade systems 
but they are not as powerful as the men folks.

Finally, the new yam festival system culturally known as "ike-jii in another period where women are robed off their rights as citizens of the community. In other words, Afikpo, Edda and Ohaozara women perpetually and politically suffer rigid marginalization. During this period, new yams are harvested from the farms which the wives accompanied their husbands to bring home. As the activities or ceremonies of the new yams are going on among men in the village square, the women are left in the kitchen preparing the yam with special soup (nsala soup) to go with. Men are later served sumptuously with pounded yam foofo, which they eat with palm wine.

To a very large extent, these cultural practices have really affected the women as women are made to run into their shelves, or hiding places when their male counterparts are seen gathering. These male counterparts in the communities are the same men that still dominate the political system at the contemporary, local, state and federal levels.

Through cultural socialisation also, Imhanlanlahimu and Eloebhose (2006), opine that girls are protected and discouraged from explorative and risky activities, while boys are encouraged to be assertive and challenge their mental power. These socialisation processes lead to certain personal characteristics regarded as masculine or feminine dependent qualities; initiative and assertiveness for boys, and dependency, submissiveness, and compliancy for girls. The later personality characteristics for girls affect their attitudes and behaviour in politics and economy.

Bamgbose (2012) defines gender as a cultural and social construct in society by which men have been culturally socialized as "self" while women become "others". These constructions are produced by the patriarchal culture of the society which designated women as inferior beings and men as superior. Men being constructed as superior beings use these advantageous positions in the scheme of culture to subjugate, marginalize and oppress women.

One of the key issues addressed at the 1995 World Conference on women in Beijing was the elimination of violence against women which also cut across ethnic, racial and cultural barriers and its prevalence is high in many cultural settings. In some cultures, physical abuse of women is often considered as an acceptable behaviour as women are often blamed for inciting men to engage in it. For instance, in Ebonyi state, beating of wives and children is widely accepted as a form of training and instilling discipline Abayomi (2014). Afro News (2007) reports that the common forms of abuse were as follows; shouting at partner (93\%), slapping or pushing (77\%), punching and kicking (40\%).

Economically, Chukwuemeka and Eze (2011) argue that Nigerian women are relegated and this is directly related to poverty. Culturally women do not own property both in their fathers' house and husbands' houses when married. With the huge amount of money involved in politics in Nigeria, women do not participate actively because they are poverty stricken. The culture of Nigeria does not allow many women into politics no matter how brilliant or skilled she is because the woman depends on the advice or support of her husband. They are created as helpers to men and so must act on instruction and by permission. Anything short of that is an insubordination and unacceptable, despite western education and exposure. Exclusion of women in political participation affects nation building, as the gender efforts are not balanced in the process.

International Institute for Democracy and Electoral Assistance (IDEA) (2003) notes that gender equity is the process of being fair to women and men. But the society is not fair in terms of gender equity to women. Even today, women continue to be left out of politics and decision making. When recognized, they are given token appointments and still addressed as those who need welfare assistance rather than actors in the historical process. In consequence, women are generally classified with children as vulnerable in society.

The subordination and exclusion of the position of women in Nigeria seems to be legitimized in the area of political participation and decision making processes. Many stories depict women as disloyal, disagreeable, untrustworthy, stupid and even gullible, (Kabira and Nzioki 1995). But a society that thinks so heads for total destruction because women are deposited with tremendous potentials that should be harnessed for societal development. To support this assertion, Asetola (2018) argues that women must be part of major development processes in any society because of their numerical strength, industriousness, and enterprising abilities and are good managers. Therefore, any national development equation without women will not be completely meaningful and thorough, especially in Africa.

According to Ebosele (2014) it is a historical misfit and disservice for any country (including Nigeria) to ignore its women population in its development efforts. Therefore, the need for effective women participation in politics should be compelling and women should be seen as partners in progress. Even Ben (2018) observed that Nigerian women value their participation very much since it confers prestige and power on them, and maintained that any attempt to plan or even implement plans without seeking full co-operation of women 
in doomed to failure. It is akin to a system of taxation without representation in governance. Furthermore, Anand (2013) confirms that the role of women in development cannot be overemphasized because Nigeria women have so far been showing the stuff they are made of. In their little ways in their communities and groups, they are not spectators on the political scene, but have been providing effective political and positive contributions to their small groups socio-economic advancement. For instance, the analysis of women's traditional and preservation responsibilities demonstrate that they have significant roles in the economy and in society such as food cultivation, food processing, food preservation, animal husbandry, marketing, and caring for their homes and families (Okereke 2017). These are very important roles which these women perform effectively with high results. If allowed to be expanded, women will collectively contribute more significantly to national development.

If we look at agriculture, the International Fund for Agricultural Development highlighted that women in particular are responsible for half of the world's food production (an opposed to cash crops) and rural women produce between $60-80 \%$ of the food in most developing countries. But Ene (2017) argues that these women's efforts on agriculture are truly undervalued even when the food security in the poor regions is often dependent on women's subsistence production to feed the population.

Egonmwan (2016) posits that women also have an important role in establishing sustainable use of resources in small scale fishing. In this study only the women in the author's clan and local government, Afikpo know how to bring fish, both dried and fresh to the market square. When empowered, they will feed the nation with fish.

Water production and management must be democratic and transparent and represent the need of the people especially women who are the primary users throughout the whole world. It has been observed that water in not often provided for use. It is the women who organize themselves in this modern time, contribute money to construct bore-hoes to serve them in the villages. African women may walk over six kilometres per day in search of water spending at least 8 hours collecting water Nwoba (2019). For a commodity that is taken for granted in more advanced countries the lack of water is an indication of lack of other things such as abundance of food, health and social welfare.

\section{DATA PRESENTATION AND ANALYSIS}

Presented below are data showing further the gross exclusion and underrepresentation of women in politics, across Nigeria. The first table is curled from data published of the Inter-Parliamentary Union (IPU). The data show the value and level of participation in politics by women of Nigeria; from 2000 to 2019; about two decades.

Table I: Value of women participation in politics in Nigeria

\begin{tabular}{|l|l|}
\hline Year & Value \\
\hline 2000 & 3.40 \\
\hline 2001 & 3.40 \\
\hline 2002 & 3.40 \\
\hline 2003 & 4.90 \\
\hline 2004 & 4.70 \\
\hline 2005 & 6.40 \\
\hline 2006 & 6.10 \\
\hline 2007 & 7.00 \\
\hline 2008 & 7.00 \\
\hline 2009 & 7.00 \\
\hline 2010 & 7.00 \\
\hline 2011 & 6.80 \\
\hline 2012 & 6.70 \\
\hline 2013 & 6.70 \\
\hline 2014 & 6.70 \\
\hline 2015 & 5.60 \\
\hline 2016 & 5.60 \\
\hline 2017 & 5.60 \\
\hline 2018 & 5.60 \\
\hline 2019 & 3.38 \\
\hline
\end{tabular}

Source: Inter-Parliamentary Union (IPU) www.Ipu.org 
A graphic representation of the above table clearly shows that within the two decades under review (2000 2019) women participation slowly climbed up by 2007, under Yar Adua / Jonathan administration, but by 2011, it had started a descent, almost a nose dive to insignificance.

Figure 1: A graph women participation in politics in the Decade $2000-20019$

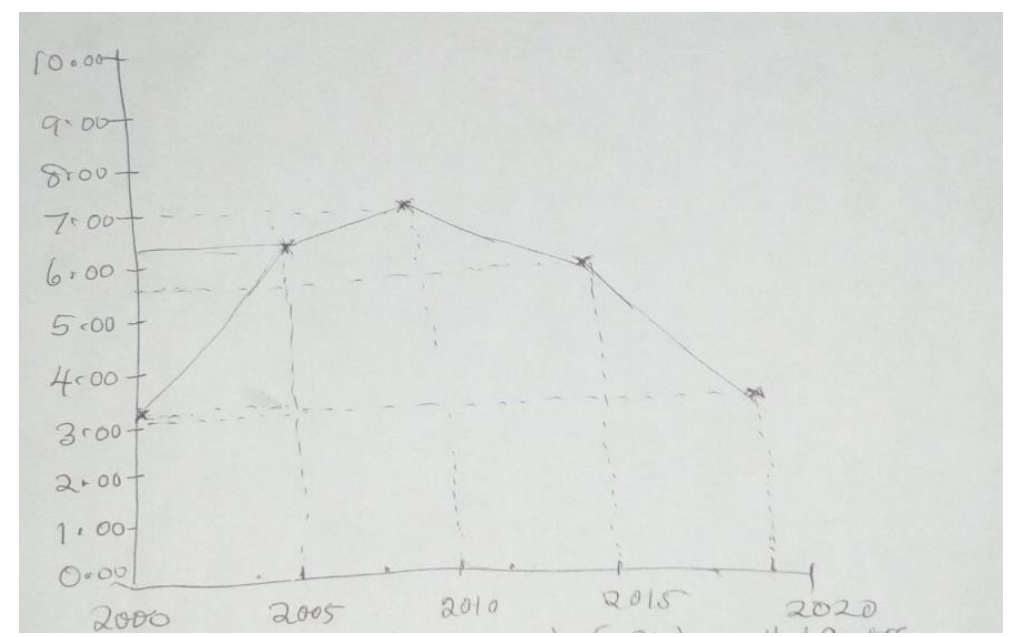

Source: Ebonyi State Electoral Commission (EBSEC) Abakaliki Nigeria.

The above graph shows token participation of Nigerian women in politics. For one thing and very important, it never peaked to 10.0 value; but hovered around the 7.00 value and nosedived back into oblivion. The years of apparent rise to 7.00 value may have taken men by surprise and they may have reasserted their possessive authority again. Civil rule came back to Nigeria after a long military interregnum, in 1999. A retired General Olusegun Obasanjo became a 'civilian' and ruled from 1999 - 2007. Between 2007 and 2015, two real civilian politicians, Umaru Yar Adua and Dr. Goodluck Jonathan, were Presidents. Within this period women participation in politics received a great boost as can be seen in the table above. When Gen. Buhari who defines the role of women as "in the kitchen and the other room" took over the mantle in 2015, women participation nosedived and continues to fall.

Further classification of political posts in Ebonyi State such as Chairmen of Local Government, members of House of Assembly, Senate and House of Representatives and so on, from 2011 to 2019 clearly show that what is above (federal) obtains 'below' (in the state).

Table II: Status of Women Participation in Ebonyi State, 2011.

\begin{tabular}{|l|l|l|l|l|}
\hline Posts & Male & Female & Total & Remarks \\
\hline Chairmen of Local Government & 12 & 1 & 13 & Male dominance is \\
clearly portrayed all \\
through
\end{tabular}

Table III: Status of Women Participation in Politics in Ebonyi State: 2015

\begin{tabular}{|l|l|l|l|l|}
\hline Posts & Male & Female & Total & Remarks \\
\hline Senate & 3 & 0 & 3 & Male dominance is clearly \\
portrayed all through \\
\hline House of Representatives & 6 & 3 & 6 & \\
\hline $\begin{array}{l}\text { Chairmen of Local } \\
\text { Government }\end{array}$ & 10 & 3 & 13 & \\
\hline State Commissioner & 9 & 3 & 12 & \\
\hline Senior Special Assistants & 4 & 2 & 6 & \\
\hline Special Assistants & 20 & 6 & 26 & \\
\hline Total & 52 & 17 & 69 & \\
\hline
\end{tabular}


IJASOS- International E-Journal of Advances in Social Sciences, Vol. VI, Issue 17, August 2020

Table IV: Status of women Participation in Politics in Ebonyi State, 2019

\begin{tabular}{|c|c|c|c|c|}
\hline Posts & Male & Female & Total & Remarks \\
\hline Senate & 3 & 0 & 3 & \multirow{3}{*}{$\begin{array}{l}\text { Male dominance is } \\
\text { clearly portrayed al } \\
\text { through }\end{array}$} \\
\hline House of Representatives & 6 & 0 & 6 & \\
\hline $\begin{array}{lll}\begin{array}{l}\text { Chairmen } \\
\text { Government }\end{array} & \text { of Local } \\
\end{array}$ & 10 & 3 & 13 & \\
\hline State Commissioner & 20 & 3 & 23 & \\
\hline Senior Special Assistants & 13 & 2 & 15 & \\
\hline Special Assistants & 20 & 5 & 25 & \\
\hline Total & 72 & 13 & 85 & \\
\hline
\end{tabular}

In the 3 years under review, namely 2011, 2015 and 2019, data presented above demonstrate without an iota of doubt that Ebonyi Women have been almost excluded from participation in the State politics, this is despite the fact that women are more than men in the State according to census figures.

\section{DISCUSSION AND SUGGESTIONS}

In discussing this paper, we have chosen the theory of patriarchy as the most enlightening in the issue of women exclusion from political participation in Nigeria, especially in Ebonyi State. According to Ritzer (2008) the situation of women in politics is essentially that of male domination, exclusion and oppression.

This type of women or female oppression in Africa in general, Nigeria in particular (with Ebonyi State as a Case Study) derive its foundation from the structure and pattern of traditional societies. This basic primitive arrangement of domination of women by men is called patriarchy. A patriarchal society is intentional, fundamental and directional in its exhibition of male dominance in the areas of power, economy and social hierarchical structures. Patriarchy derives its raison detre and summon bonum from quintessential sources and justification such as nature (heredity) and nurture (socialization), religion and sex-role identities, or even a rigid class system. All these project a peculiar power arrangement that makes women deficit while men have a head start in the handicap chase of power. To this extent all theories of gender oppression, gender differences and gender inequality are derived from the patriarchy structure of society. Men are born and socialized to dominate while women are born and socialized to be dominated. Indeed, some gender theorists argue that women are socialized to fear success, position of dominance and acclaim.

This can explain why there has been very little success in the areas of gender equality and affirmation, despite the many declarations at the international level, of which Nigeria is a signatory; examples are the Cairo Conference of 1994, the Beijin Conference of 1995 on gender equality.

In most parts of Nigeria, Patriarchy is rigid and unwavering because of entrenched hedonistic and atavistic traditional rituals, religious beliefs and practices. The consequences are what we have shown in the paper, with data and theories. No woman marries a man in Nigeria, therefore, no woman can head a family. If a woman cannot head a family, the traditional patriarchs argue, how can a woman rule a society in any political arrangement? Narrow and myopic as the perception may look, traditional societies are often built on false perceptions and assumptions.

In Nigeria, the low participation of women in politics and legislative position has affected the ability of women in promoting favourable legal and regulatory arrangements of laws for the promotion of gender equality and women participation in politics. When you take a look at the tables provided so far (Tables I-IV) from Ebonyi State; no effective legislation in favour of women can be achieved in their absence. Between 1999 and 2007 in Ebonyi State House of Assembly, in the absence of any woman, a man was appointed to take charge of "Women Affairs". Rotate this picture or scenario in 36 States and 774 local governments of Nigeria, and a very pathetic trend begins to emerge.

There are two legs in Patriarchy theory of male domination, namely;

a) Psychoanalytic feminism, and

b) Radical feminism.

In Psychoanalytic patriarchy, the structure of male dominance is so pervasive that it has taken hold of the female psyche in traditional societies. Occasionally, women have sprung up to challenge this domination by men and even try to upset the existing status quo, in some radical ways. In Nigerian history the stories about "Queen Amina of Zaria", "Queen Moremi of Ile-Ife" or the Aba women riots of 1929; have become legendary. However, such eruptions quickly cool off and women go back to their accepted traditionally assigned roles which exclude power dominance. According to Lengermann and Niebrugge (2008), men have deep seated emotions and motivation to control women; though all men are reared by women but traditional rituals of 
male initiation very early in life, separate a boy from the influence of his mother. From then on, the male boy looks down on the mother and boldly tells the mother that many secrets of menfolk cannot be divulged to women. This is the beginning of traditional male power dominance over women.

Another perspective that can be used to inspect the obnoxious theory of patriarchy is the radical theory which is essentially Marxist. According to Marx, human exploitation and degradation, in this case, by men of women, is based on three planks, namely

a) Denial of women the means of production

b) Denial of women the mode of production

c) Denial of women their property rights.

By these three denials women's capacity to operate fully in the social-economic and political domains of a country like Nigeria are permanently halted.

Women are denied the land which is a major means of production. The denial of land also relates to the denial of inheritance which forecloses the ability of women to; for example, have cocoa, tea, palm, rubber, cashew, plantations or groundnut farms from where they can generate money for political participation.

Similarly, women are denied the mode of production since the woman do not have nor keep farming implements: this is a purely bourgeois damaging method which Marx upbraided in his "Critique of Bourgeois Political Economy. Without work or the means to gainful activity women are totally incapacitated. Habermas (1972) sees work as a dominant form of social action and reaction, without which women cannot participate meaningfully in the ongoing political and economic society. Work has "purposive rationality" which stresses the importance of goal attainment, defined in terms of means-end relationship. This mode of alienation of women by men is a system of power and domination which pervades the totality of the Nigerian Society.

Indeed, the preclusion of women from political participation has a precarious ontological status which normally develops in Nigeria a subjectivity approach to political engineering and social development. The exclusion of women makes a country a one handed bandit which is almost dysfunctional and useless. It makes full gender interaction in the political sphere almost impossible in Nigeria.

Marx's model of society is basically divided into two, namely "the substructure" (foundation) of society which is the economic base; and the "super structure" which is superimposed on the foundation and includes the polity. That women are alienated from the substructure generates alienation on the superstructure and this leads to contradiction which makes women stand in antagonistic relationship to men, hence feminism.

Thirdly, without the means of production or its mode, it is easy to see that women will not have the right to property. In most Nigerian and Ebonyi Societies, women have no right to land and therefore no right to property. In any village, town or city men own almost all the land and property. With property rights or title deeds, men can go to the Banks to get loans to run for political offices. If the men win they pay back; but where they fail their property is sold off to the Banks. Women in general do not have such luxury and that is a paradox; a serious contradiction. Unless the above three identified issues are radically changed it will not be possible for women to play the same league as men in Nigerian politics, this is the nexus of this paper which calls for drastic and timely changes in the structure of society.

\section{CONCLUSION AND RECOMMENDATIONS}

This paper has examined the issue and problem of women exclusion from political participation in Nigeria, with a case study of Ebonyi State. Data have clearly indicated that the extent of exclusion is staggering in the last two decades and if changes are not brought in to bear on the contemporary political and economic life of Ebonyi women, the next decades will still present the current pattern and trend of political apartheid.

The paper therefore makes the following suggestions and recommendations:

1. Nigeria is a signatory to all international conventions on gender equality and woman rights. External pressures from the various conventions should be brought to bear on Nigeria since the hope of internal enforceability of the recommendations is bleak in the foreseeable future.

2. Women are achievers to doubt, as those few who have been given the opportunity have demonstrated in Nigeria. More women should therefore be given more appointive positions in government, to enlarge their experiences and capacity for future elective positions.

3. Women are more in number than men; they should therefore unite and become a formidable political force in the state and country. 
4. Economic power is the basis for political power. More women should become more economically endowed in order to run for political offices.

5. Knowledge is power and knowledge comes from education, training and skills acquisition. The Millennium Development Goals (MDG) of 2000-2015 did not do much to enhance the education of women in Nigeria. The current Sustainable Development Goals (SDG) 2015-2030 should be focused among others, in raising the literacy levels of women in Nigeria, especially Ebonyi State.

6. The perception of women by men needs social reengineering of their attitudes.

7. A special scholarship scheme for the education of the girl child up to womanhood should be instituted in all states of Nigeria; especially in Ebonyi State.

8. A political empowerment endowment fund for women (PEEF-W) should as matter of urgency be set up in Nigeria and Ebonyi State. Through the fund women can be economically empowered to become politically empowered.

9. All traditionally and culturally harmful practices against women should be abolished in Nigeria.

10.Women should form a political party of their own. Politics is a game of numbers, so women like the Labour party of Britain formed in 1948, should use their own party to gain power politically.

\section{REFERENCE LIST}

Adetola, I. F. (2018). Women Empowerment as a measure of Good Governance in Nigeria, International Journal of Natural and Applied Science, 5(2): 167-173

Agbalajiobi, T. D. (2010). Women's Participation and the Political Process in Nigeria: Problems and Prospect. African Journal of Political Science and International Relations $(4,2)$

Amiu, S. O (2016) Gender Equality Factors Hindering Females Participation in Politics. https://www.worldpulse.com?.port91112020

Anand C. I. (2013). Women and the Development process: A study of Rural women's Organisation in Community Development in Nigeria. In Yomi

Anifowose, R. (2014). Women Political Participation in Nigeria: "Problem and Prospect". In Akinboye (ed) Paradox of Gender Equality in Nigerian Politics. Lagos, Concept Publications

Anifowose, R. (2004). Women Political Participation in Nigeria: Problems and Prospects. In Akinboye S. (Ed), Paradox of Gender Equality in August 29-31.

Attoe, E. S (2002) Skepticism of Women in Nigerian Governance and politics: A historical Metamorphoses of a Prey Turning Predator, Precolonial Times Till Date

Attoe, E. S (2002) Women in the Development of Nigeria Sinie Precolonial Time.

http://www.enhenigeria.com/links/adv.asp? blurb $=150 \# 1 * 222^{*} \mathrm{dbu}^{*} 13 \mathrm{c}$

Badejo, O (1985) Women And The Political History of Nigeria - WIRED Space. wired space wits

Bamgbose G. (2012). Modern Africa Poetry and Issue of Gender: The Nigeria Literary Science: Research on Humanities and Social Science Vol. 2, No11

Ebosele, F. O. (2014). Feminist Theory and International Relations. The Feminist Challenge to Realism and Liberalism.

Egwu, E. U and Egwu J. U (2007). Political Culture and Behaviour in Nigeria: Abakaliki. Caleb Publishing

Egwu, J. U (2017) Constitutional Changes And Political Development In Nigeria Abakaliki-Nigeria. Copy Craft International Company

Egwu, J. U (2017) Political Behaviour And Participation in Nigeria. Nigeria Scholastic Publication And Services (SPS).

Egonmwan, C. O. (2016). Women Participation in Party Politics During the Multiparty Era in Africa: The case of Tanzania (electronic version). EISA Occasional paper, 34, 1 -14.

Ekpe. D. E, Eja. A. E and Egbe, J. I (2014). Women Gender Equality in Nigeria: A critical Analysis of SocioEconomic and Political (Gender Issues). Journal of Research Peace Gender and Development: Vol 4 
(1) pp.15-20

Ene, J. I. (2017). Gender Inequality, Income and Growth: Are God Times Good for Women? (Vol. 1). Washington, D.C. Development Research Group, The World Bank.

Habermas J. (1972) Knowledge And Human Interests, London, Heinemann

International Institute for Democracy and Electoral Assistance (IDEA) (2003) Capacity Building for Mainstreaming Gender Equality. Garamond Georgia

Imhanlahimi, E. and Loeb Hose, F. E (2006). Problems and Prospects of Women Access to Science and Technology Education in Nigeria. Vol 40.

Kabira, W. M. and Nzioki, E. A. (1995) Celebrating Women's Resistance. A case study of Women Group Movement in Kenya Nairobi.

Luka, R. C. (2011). "Women and Political Participation in Nigeria: The Imperative of Empowerment: Journal of Social Science and Public Policy Vol. 3.

Marx K. (2001). Women and Empowerment: Participation and Decision making London, Zed Books Ltd

Marcellus I. O (2009) Development Planning in Nigeria. Reflection on National Economic Empowerment And Development Strategy (NEEDS) 2003 Journal of Social Sciences 20 (3), 197-210

Nwoba, J. C. (2019). Impact of women Participation in Nigerian Politics and National Development: A Study of Ikwo Local Government Area of Ebonyi State. Unpublished MSc Dissertation

Obasanjo, A. O (2007) "Psychology and National Development “. This Day Newspaper. October 5, 2007

Obura, D. A. (1991). Changing Images. A Portrayal of Girls and Women in Kenya. Text Books. Nairobi Acts Press.

Olatunde D. (2010) Women Participation and Representation in Nigerian Politics 1999-2009: Gender Issues in Nigerian Politics https://www.amazon.com>participa....

Okereke, R. B (2017). Empowerment of Nigerian Women Towards National Development in Journal of Resourcefulness and Distinction. Vol. 2

Okpuike, A. (2013). Sociological Explanations of Male Dominance in Nigerian Party Politics: Implication for Education, Society and Behavioural Science. Vol. 3, (2) 154-462

Oruwari (Ed): Women Development and the Nigerian Environment Ibadan: Vintage Publisher

Federal Republic of Nigeria Amended Constitution 2010

Orucha, G. (2018). Participation of Women in Political Life. Geneva: Inter-Parliamentary Union. Ibadan University Press Plc.

Organization For Economic Co-operation And Development (2018)

Statistics of Sweden (2016). Women and Men in Sweden: Facts and Figures 2016. https://www.sib.se/statistics/publikationer/LEO201 2015B16.BR*10BR1601 ENG. PDF

UN Women (2015) Gender Equality, Women's Empowerment and Climate Change https://www.unwomen.org

UN Decade Report (1980) Report of the World Conference of the UN Decade Women: Quality, Development and Peace. Copenhagen full. https://www.unorg.beijing PDF.UN.New York.

UNDP Report (2015). Women in Parliamentary 2007: The Year in Perspective. Retrieved on $18^{\text {th }}$ September, 2019 from website. www.ipu.org.

Umer, S. O and Hassan K. (2010). Male Dominancy. International Journal of Business and Social Sciences. Vol. 7. No. 10

Wajadu (2008). Special Issue: Women and Activism for Gender Equity in Africa Vol.6.

Wood, J. (2018) These Four Nordic Countries Hold the Secret to Gender Equality World Economic Forum https://www.weforum.org.

Yetunde, A. (2008). Nigerian Women in Politics: A Study of The Role of Women In Obasanjo Administration (1999-2007). 